\title{
In vitro anthelmintic activity of pineapple peel juice (Ananas comosus (L.) Merr.) against Paramphistomum sp.
}

\author{
Siska Yunita Damiyatia, ${ }^{\mathrm{a}}$, Iman Surya Pratama $^{\mathrm{a}}$, Galuh Tresnani ${ }^{\mathrm{b}}$ \\ ${ }^{a}$ Department of Pharmacy, Faculty of Medicine, Mataram University, Mataram 83125, Indonesia \\ ${ }^{b}$ Department of Biology, Faculty of Mathematics and Natural Science, Mataram University, Mataram 83125, Indonesia
}

\section{Article history:}

Received: 19 May 2021 / Received in revised form: 7 June 2021 / Accepted: 10 June 2021

\begin{abstract}
Pineapple peel (Ananas comosus (L.) Merr.) has a potential natural-based anthelmintic agent. This study aimed to determine the effective concentration of pineapple peel juice against Paramphistomum sp. in vitro. Adults Paramphistomum sp. were divided into 5 test groups, the control group contained Albendazole $10 \% \mathrm{w} / \mathrm{v}$, the nontreatment group contained $\mathrm{NaCl} 0.9 \%$ w/v and the treatment group contained pineapple peel juice with concentration of $12.5,20$, and $25 \% \mathrm{w} / \mathrm{v}$. The number of live flukes and the motility scores were recorded every 15 minutes for 5 hours of incubation. The Survival Index (SI) and Relative Motility (RM) of flukes were calculated and statically analyzed using SPSS version 23 software. SI values of flukes in the $12.5,20$, and $25 \%$ w/v concentration of treatment group were 46.3 , 50.0, and $38.9 \%$ respectively. RM values of flukes in the $12.5,20$ and $25 \%$ w/v concentration of treatment groups were 39.1 , 42.0, and 34.1 respectively. RM values of flukes in the 12.5, 20 and 25\% w/v concentration of treatment groups were 39.1359, 42.0249, and 34.1174 respectively. This research showed that, pineapple peel juice $25 \% \mathrm{w} / \mathrm{v}$ was effective against Paramphistomum sp. with survival index and relative motility values comparable to Albendazole $10 \% \mathrm{w} / \mathrm{v}(\mathrm{p}<0.05)$.
\end{abstract}

Keywords: Pineapple Peel Juice; Anthelmintic; Paramphistomum sp

\section{Introduction}

Paramphistomiasis is an infection caused by the flukes Paramphistomum sp. from Paramphistomatidae family [1]. These flukes infect ruminants such as cattle, sheep, and goat, particularly in ruminants with poor body conditions [2]. The infection of Paramphistomum causes tissue damage because the flukes penetrate the small intestinal wall and migrate into the rumen of livestock [3]. Paramphistomiasis is distributed all around the world with the highest prevalence reported in tropical and subtropical regions, particularly in Africa, Asia, Australia, Eastern Europe, and Russia [4].

The prevalence of paramphistomiasis in West Nusa Tenggara including the one recorded by Denpasar Veterinary Center was found to be $24.27 \%$ in 2016 . The identification result showed that the highest prevalence of trematodosis occurred in Central Lombok and Mataram [5].

Paramphistomum infection is frequently overlooked although the flukes have a major impact on the health and productivity of livestock [6]. The infection of these flukes causes losses including inhibiting ruminants' growth, damaging tissues or organs, and reducing body weight. This impact can cause heavy losses for farmers, including a decrease in economic value of livestock and an increase in production

* Corresponding author.

Email: siskayunita38ixa@gmail.com

https://doi.org/10.21924/cst.6.1.2021.394 costs due to drug use $[7,8,9]$. Non-pharmacological control of paramphistomiasis is carried out by maintaining the hygiene of feed and cowshed, drying trenches, avoiding livestock grazing during rainy season, and caring for livestock in dry season [10]. Pharmacological control is carried out by administering synthetic anthelmintics such as Albendazole, Niclosamide, Resorantel, or a combination of Oxyclozanide-Levamisole $[11,12,13]$.

Several studies have reported resistance to the use of synthetic anthelmintic including Albendazole due to frequent and inappropriate use [14]. Medicinal plants can be used as an alternative to overcome the limitations of synthetic anthelmintics. Medicinal plants are easy to obtain, process and administer to livestock [15]. Secondary metabolites of plant work synergistically with various mechanisms, thereby reducing the risk of side effects and resistance [16,17]. Garlic (Allium sativum), goldenseal (Hydrastis canadensis), and papaya (Carica papaya) are some of the natural anthelmintics that are widely used by the community [18]. Pineapple peel or Ananas comosus (L.) Merr. has the potential as a natural anthelmintic [19].

According to Widodo, pineapple peel juice at a dose of $40 \mathrm{~g}$ per kg of body weight was able to reduce the number of eggs of Paramphistomum sp. in Bali cattle with an egg reduction rate of $100 \%$ comparable to Albendazole as a positive control with a 95\% confidence level [20]. Research on the effectiveness of pineapple peel against Paramphistomum adults is still limited 
[21]. This study aimed to determine the effective concentration of pineapple peel juice (Ananas comosus (L.) Merr.) against Paramphistomum sp. in vitro.

\section{Materials and Methods}

\subsection{Collection of adult Paramphistomum sp.}

Adult Paramphistomum were collected from Majeluk Slaughterhouse, Mataram City, Lombok, West Nusa Tenggara, Indonesia. Flukes were collected from the rumen and reticulum of the cattle. The flukes were collected in a jar containing a warm $0.9 \%(\mathrm{w} / \mathrm{v}) \mathrm{NaCl}$ solution. Two hours after collection, the flukes stored at $37^{\circ} \mathrm{C}$ were then selected for identification and in vitro anthelmintic test. The selected flukes of this study were actively mobile and had a relatively uniform size.

\subsection{Morphological identification}

Adult Paramphistomum were identified by observing the shape, color, size, oral sucker, acetabulum, testes, and caecum. The identification was carried out by a whole-mount preparation. Flukes were clamped between two glass objects and fixed with $70 \%(\mathrm{v} / \mathrm{v})$ alcohol. The specimens were immersed in natural dye from red beetroot $100 \mathrm{~g} / 100 \mathrm{~mL}$ and synthetic dye from Acetocarmine $1 \mathrm{~g} / 100 \mathrm{~mL}$ for 24 hours.

Beetroot dye was made following the preparation by AlAmura et al. with a few modifications, $100 \mathrm{~g}$ of beetroot pieces were boiled in $100 \mathrm{~mL}$ of water for 1 hour, then the solution was filtered [22]. Acetocarmine ${ }^{\circledR}$ dye was prepared by dissolving $1 \mathrm{~g}$ Acetocarmine ${ }^{\circledR}$ powder in $100 \mathrm{~mL}$ water and filtered using filter paper [23]. The specimen was washed with acid alcohol (2 mL HCl in $100 \mathrm{~mL} \mathrm{70 \%} \mathrm{(v/v)} \mathrm{alcohol)}$

The specimens were dehydrated into $70,80,90$, and $96 \%$ (v/v) alcohol. The specimens were cleared with methyl salicylate and mounted with Entellan ${ }^{\circledR}$. The morphology was identified according to the literature by Mehlhorn et al. [24].

\subsection{Preparation of pineapple peel juice}

The pineapples were obtained from Lendang Nangka Village, Masbagik Sub-district, East Lombok District, West Nusa Tenggara Province. The sample was identified in the Advanced Biology Laboratory of Plant Ecology and Biosystematics, Department of Mathematics and Natural Sciences, Mataram University. Based on determination letter No. 10/UN18.7/LBL/2020, the sample has been confirmed to be Pineapple (Ananas comosus (L.) Merr.).

Pineapple was peeled and the peels were weighed, sorted, cleaned, and cut. The pineapple peel pieces were then blended with water to obtain a juice solution with a concentration of $25 \% \mathrm{w} / \mathrm{v}$. Pineapple peel juice $25 \% \mathrm{w} / \mathrm{v}$ was then diluted to a concentration of $20 \% \mathrm{w} / \mathrm{v}$ and $12.5 \% \mathrm{w} / \mathrm{v}$ [52] Pineapple Peel Juice is further abbreviated as PPJ.

\subsection{In vitro anthelmintic test}

These tests were divided into 5 test groups, the treatment group contained pineapple peel juice $(12.5,20$, and $25 \% \mathrm{w} / \mathrm{v})$, the negative control group contained $\mathrm{NaCl} 0.9 \% \mathrm{w} / \mathrm{v}$ and the positive control group contained Albendazole 10\% w/v. Each petri dish was filled with the solution of each test group and incubated for 30 minutes at $37^{\circ} \mathrm{C}$. The flukes were incubated in petri dishes containing the solutions at $37^{\circ} \mathrm{C}$. Each test group contained 3 flukes.

The flukes' mortality was observed one by one in each fluke every 15 minutes for 5 hours of incubation. The flukes' motility at each incubation period was assessed using the criteria from Lorsuwannarat et al [25]. Flukes without motility were stained with $1 \% \mathrm{w} / \mathrm{v}$ methylene blue dye diluted in $0.9 \% \mathrm{w} / \mathrm{v} \mathrm{NaCl}$ for 2 minutes. The in vitro test was carried out with 3 replications.

\subsection{Data analysis}

Relative Motility of flukes were determined using the following formula [25]:

MI $($ Motility Index $)=\frac{\left(\sum n N\right)}{\left(\sum N\right)}$

$\mathrm{RM}\left(\right.$ Relative Motility) $=\frac{(\text { MI test } x 100)}{(\text { MI control })}$

$\mathrm{n} \quad=$ Motility Score

$\mathrm{N} \quad=$ Numbers of flukes in each group

The survival index of flukes was calculated by the following formula [25]:

$$
\text { SI }(\text { Survival Index })=\frac{\text { (Numbers of live flukes })}{(\text { Numbers of all flukes })}
$$

The data were analyzed statistically using SPSS version 23 A normality test was performed to find out whether the data were normally distributed or not. Hypothesis testing with One Way ANOVA was carried out if the data were normally distributed then the analysis was continued with the Post Hoc LSD test. Kruskal Wallis test was carried out if the data were not normal and followed by the Post Hoc Mann-Whitney U Test.

\section{Results and Discussion}

\subsection{Morphological identification}

Based on the macroscopic observations in figure 1 , the flukes were oval, pink, 7-10 mm long, and 2-3 mm wide. These observations indicated that the flukes had a similar morphology to Paramphistomum sp. [24,12,26]. Microscopic identification was carried out by observing the morphology of the whole preparations of flukes stained by red beets as natural dyes and acetocarmine as synthetic dyes.

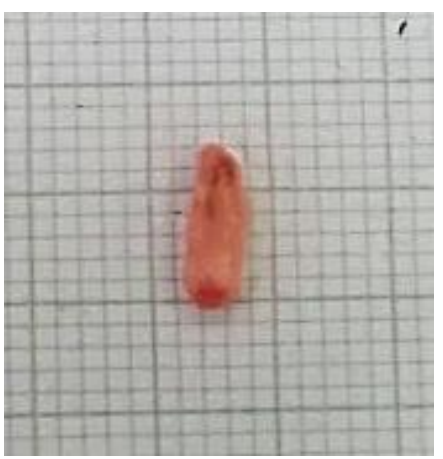

Fig. 1. Morphological identification of Paramphistomum sp. 
Based on figure 2 (a) and (b), preparations with 40x magnification showed the morphology of Paramphistomum sp. according to references by Mehlhorn et al. The oral suction cavity was located at the anterior end, while the acetabulum was located at the posterior end [26]. The anterior cecum of the flukes branched into two [27]. On two lateral sides, there were vitellary glands, while in the middle near the cecum there were genital pores [24,11]. Two testes were located in the middle of the fluke's body [28].

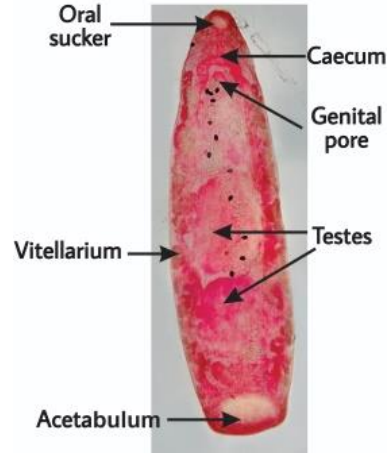

(a)

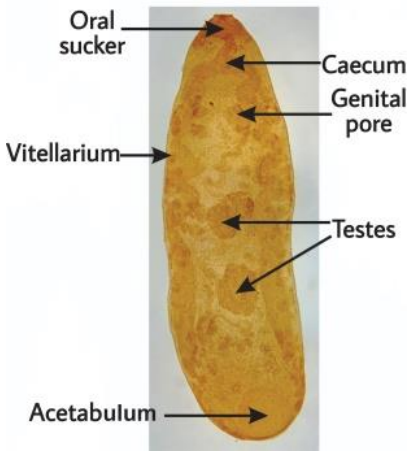

(b)
Fig. 2. Morphological identification of whole mount of Paramphistomum sp.: (a) Red Beet staining; (b) Acetocarmine staining

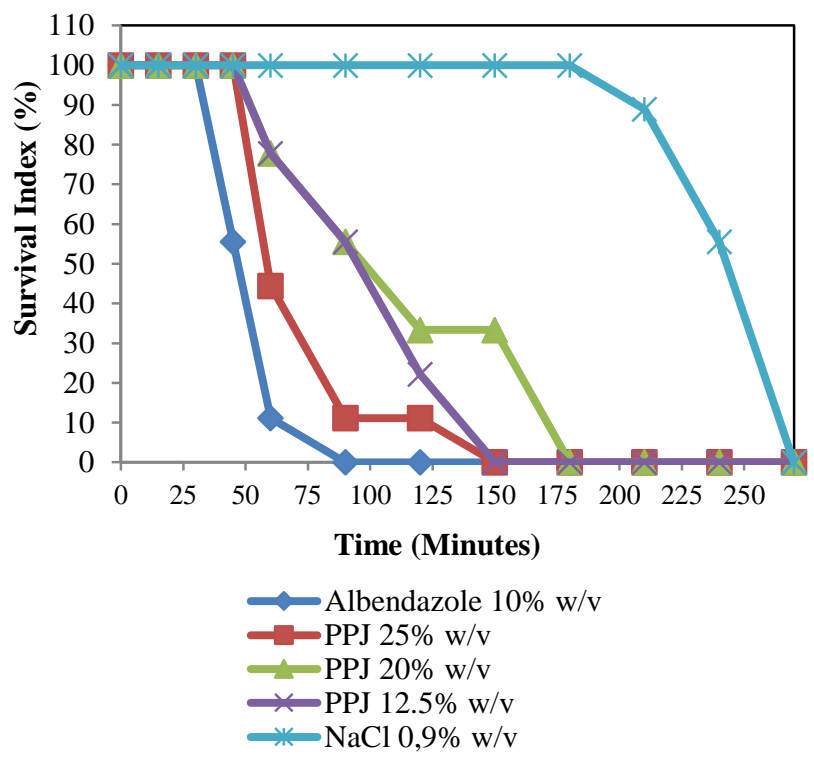

Fig. 3. Survival index mean

Beetroot dye with a concentration of $100 \mathrm{~g} / 100 \mathrm{~mL}$ was made by boiling process for 1 hour. The whole-mount specimen that had been soaked for 24 hours produced a yellow color. This color came from the pigment betaxanthin as part of betalain in red beet [29]. Betalain has a carbonyl group which is in an acidic condition will react with amino protein groups and will form salts with alkaline proteins [30].

Betaxanthin is formed through a condensation reaction between amino acids or amines with the aldehyde group of betalamic acid. Betalamic acid is the main chromophore of betalain which plays an important role in the staining process [31]. Betalamic acid causes the water extract of red beet to have an acidic $\mathrm{pH}$. This allows alkaline structures such as cytoplasm, nerve fibers, muscle fibers, mucin, keratin, and red blood cells to be stained [30].

Specimen with $1 \%$ w/v Acetocarmine dye produced carmine red color as shown in figure 2 (b). The mechanism of Acetocarmine is the fine carmine particles enter the cell, then the molecules are aggregated into larger particles.This aggregation occurs due to the low $\mathrm{pH}$ in the cell proteins. The diffusion process is further inhibited which leads the carmine molecules to be trapped in the cell [32].

Red beet and Acetocarmine were able to stain all the main morphologies of Paramphistomum sp. Therefore, natural red beet dye has the potential as a dye for whole mount preparations of Paramphistomum sp. Beetroot has been used by industry as a natural food coloring agent [33]. Some studies also suggest that beetroot has the potential to dye textiles, wood, and leather. The use of natural dyes is believed to be environmentally friendly and non-carcinogenic so that it can reduce health and environmental problems due to the use of synthetic dyes $[34,35]$

\subsection{In vitro anthelmintic activity}

Albendazole $10 \% \mathrm{w} / \mathrm{v}$ was used as a positive control because it is a broad-spectrum anthelmintic drug that can kill various types of trematodes [36]. A concentration of $10 \% \mathrm{w} / \mathrm{v}$ was chosen according to Purnamasari, Albendazole 10\% w/v was effective against adult Paramphistomum [37]. There is a recommendation from Hossain et al. and Saowakon et al. to increase the concentration of Albendazole, because the concentrations of $100 \mu \mathrm{g} / \mathrm{mL}$ and $10 \mathrm{mg} / \mathrm{mL}$ used in both studies had a weak anthelmintic effect $[38,39]$.

Physiological saline solution was used as a negative control for isotonic properties of flukes so that it did not damage the cell membrane [40]. The PPJ treatment concentrations of 12.5, 20 , and $25 \% \mathrm{w} / \mathrm{v}$ were chosen because they were ovicidal to Paramphistomum sp. [20]. The parameters measured in this study were the survival index and the relative motility of flukes. Survival Index (SI) is the percentage of flukes that live at a certain time after being given treatment [41].

The SI values are shown in figure 3 . The lowest and highest fluke survival rates were shown by positive control and negative control, respectively. Albendazole as a positive control has been known to have an anthelmintic effect with the following mechanisms: it binds to $\beta$-tubulin so that it inhibits polymerization and formation of fluke tubules, inhibits glucose intake, occurs glycogen depletion which slowly results in fluke death $[36,42]$.

The highest survival in the $\mathrm{NaCl} 0.9 \% \mathrm{w} / \mathrm{v}$ solution group showed no anthelmintic effect. Among the three PPJ treatment groups, flukes in the PPJ $20 \% \mathrm{w} / \mathrm{v}$ group had the longest survival. Flukes in the $25 \% \mathrm{w} / \mathrm{v}$ and $12.5 \% \mathrm{w} / \mathrm{v}$ PPJ groups experienced death simultaneously at the 150th minute. Even though, the decline in survival at PPJ $25 \%$ w/v was steeper than PPJ $20 \%$ w/v.

The fluke mortality was identified by the flukes stained with $1 \%$ methylene blue. Living eukaryotic cells were able to reduce methylene blue enzymatically which caused the color to fade and the cells were not stained. The dead cells were unable to reduce methylene blue, it caused the oxidation of methylene blue and the cells were stained blue to black [43].

The SI values of each group were then compared statistically. The results are summarized in the graph in figure 
4. The graph shows that there is a significant difference between positive and negative controls $(p<0.05)$, with the positive control SI value being lower than the negative control. This shows that the fluke survival in the positive control group was lower than the negative control. The SI value in the PPJ group was lower and significantly different from the negative control, meaning that the fluke survival in each treatment group was lower than the negative control $(\mathrm{p}<0.05)$.

The $25 \% \mathrm{w} / \mathrm{v}$ PPJ group was not significantly different from the positive control. This suggests that the effect produced by the PPJ $25 \% \mathrm{w} / \mathrm{v}$ group was comparable to that of the positive control. The Relative Motility (RM), was calculated from the score of the motility of the flukes after being exposed to the test solution. The smaller the RM value, the stronger the drug activity [41].

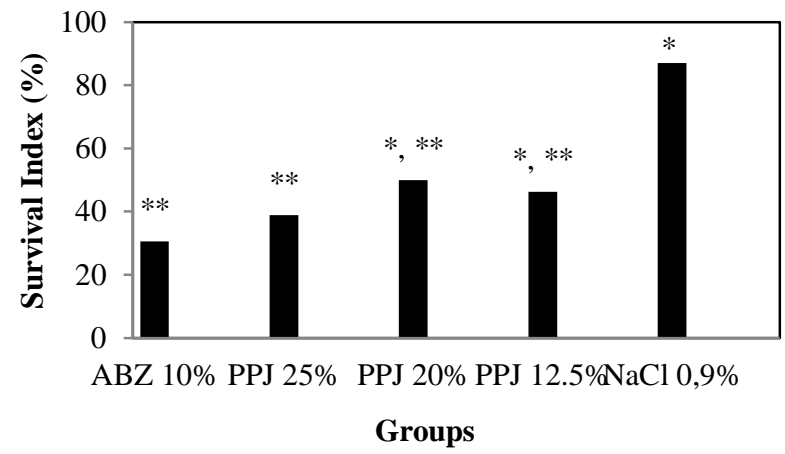

Fig. 4. SI mean of each group: * significantly different from Albendazole $10 \% \mathrm{w} / \mathrm{v}, * *$ significantly different from $\mathrm{NaCl} 0.9 \% \mathrm{w} / \mathrm{v}(\mathrm{p}<0.05)$

The RM value is shown in figure 5. Flukes in the negative control group showed active motility from 0-240 minutes. Meanwhile, the motility of the flukes weakened after being exposed to Albendazole and all PPJ concentrations. Flukes at the three concentrations of PPJ lost their motility and died simultaneously at 150 minutes, however, the reduction in RM per unit time was different. The most passive and most active motilities among the PPJ treatments were shown by PPJ $25 \%$ $\mathrm{w} / \mathrm{v}$ and PPJ $20 \% \mathrm{w} / \mathrm{v}$.

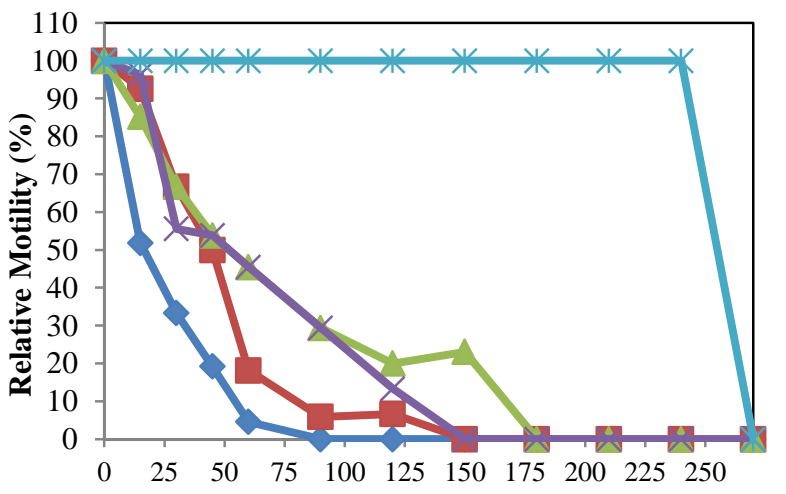

Time (Minutes)

Albendazole $10 \% \mathrm{w} / \mathrm{v}$
- PPJ $25 \% \mathrm{w} / \mathrm{v}$
$\sim \mathrm{PPJ} 20 \% \mathrm{w} / \mathrm{v}$
$\approx \mathrm{PPJ} 12,5 \% \mathrm{w} / \mathrm{v}$
$\mathrm{NaCl} 0,9 \% \mathrm{w} / \mathrm{v}$

Fig. 5. Relative motility mean

The RM value of each test group was then processed statistically. The statistical test results are presented in figure 6.
Based on the graph, there is a significant difference between the positive and negative control groups $(\mathrm{p}<0.05)$, with the positive control SI value being lower than the negative control. This shows that the motility of flukes in the positive control group was more passive than the negative group. The RM value in the PPJ group was lower and significantly different from the negative control, meaning that the fluke survival in each treatment group was lower than the negative control ( $\mathrm{p}<0.05)$. All PPJ groups were not significantly different from the positive controls so that the effects produced by the two groups were comparable.

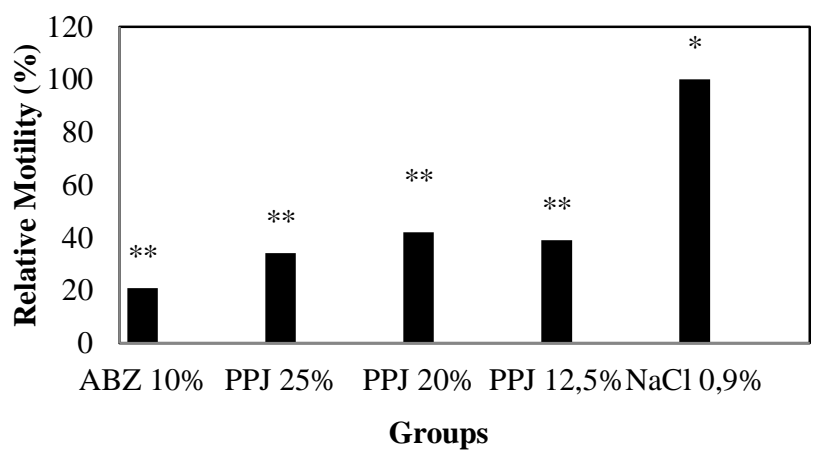

Fig. 6. RM mean of each group: * significantly different from Albendazole $10 \% \mathrm{w} / \mathrm{v}, * *$ significantly different from $\mathrm{NaCl} 0.9 \% \mathrm{w} / \mathrm{v}(\mathrm{p}<0.05)$

Based on the statistical analysis, it shows that Albendazole and PPJ have anthelmintic effects $(\mathrm{p}<0.05)$. Saowakon et al. explained the anthelmintic mechanism of Albendazole with damage to adult Paramphistomum flukes. Albendazole binds to $\beta$-tubulin and interferes with the formation of flukes' microtubules. Gradually this causes damage to the surface of the tegument, therefore water enters the surface of the tegument and causes an osmotic imbalance. Blebbing occurred in papillae around oral suction vanity [39].

Albendazole also damages the folds on the surface of the flukes' body. Damage to the folds of the tegument on the acetabulum can interfere with the attachment of flukes to the rumen tissue of the host. Tegument damage can also interfere with flukes' physiological processes such as protection, secretion and synthesis [44,39].

The secondary metabolite compounds have been determined qualitatively by Damiyati et al. Based on the previous study, PPJ contains tannins, alkaloids, flavonoids, saponins, and triterpenoids that have anthelmintics activity [52]. Tannins bind to proteins in the flukes that interfere with motility, absorption of nutrients and cause death [45]. Flavonoids denature proteins in the fluke's body tissue which cause paralysis and death of flukes [46].

Alkaloids act on the central nervous system causing paralysis and death of flukes [47]. Saponins can increase the permeability of cell membranes resulting in vacuolization and disintegration of the tegument [48]. The mechanism of triterpenoid is to interfere with the surface of the tegument membrane, mitochondrial dysfunction, and inhibition of the lipase enzyme [49].

PPJ $25 \% \mathrm{w} / \mathrm{v}$ is potential as an alternative treatment for intestinal flukes because the effect is comparable to Albendazole ( $p$ <0.05). In this study, increasing the concentration did not cause an increase in the anthelmintic effect, but the effect was the same at each concentration. This is presumably due to the selection of the concentration range 
which was still too narrow so that the optimal effect was only seen in the $25 \%$ PPJ.

Based on an in vivo study by Widodo, PPJ $20 \%$ was known to be the most effective concentration in reducing the number of eggs, meanwhile in this study PPJ $25 \%$ was the most effective concentration against adult Paramphistomum sp. The difference in concentration is thought to be because, in the in vivo test, the activity of bioactive compounds is affected by the biological activity of cattle. Physicochemical factors that can affect drug levels such as digestive enzymes, $\mathrm{pH}$, and ruminal flora. Ruminal flora plays an important role in drug bioavailability because it can change the efficacy of drugs through the biotransformation process [50].

In addition, the content of tannins in PPJ can affect digestive enzymes in cattle. Tannins are large molecules that can bind to proteins in digestive enzymes to form complexes. The higher the concentration of the tannins, the more tannin-protein complexes formed causing low solubility. This may cause the tannins in a high concentration of PPJ to be difficult to penetrate the membrane [51]

\section{Conclusion}

The concentration $25 \%$ w/v Pineapple Peel Juice is effective to kill Paramphistomum sp. with survival index and relative motility values comparable to Albendazole $10 \% \mathrm{w} / \mathrm{v}$. SI values of flukes in the $12.5,20$, and $25 \% \mathrm{w} / \mathrm{v}$ concentration of treatment group were $46.3,50.0$, and $38.9 \%$ respectively. RM values of flukes in the $12.5,20$ and $25 \% \mathrm{w} / \mathrm{v}$ concentration of treatment groups were $39.1,42.0$, and 34.1 respectively.

\section{References}

1. C. Mage, H. Bourgne, J-M Toullieu, D. Rondelaud, and G. Dreyfuss, Fasciola hepatica and Paramphistomum daubneyi: Changes in prevalences of natural infections in cattle and in Lymnaea truncatula from central France over the past 12 years, Vet. Res. 33 (2002) 439-447.

2. S. Melaku and M. Addis., Prevalence and intensity of paramphistomum in ruminants slaughtered at Debre Zeit Industrial Abattoir, Ethiopia, Glob. Vet. 8 (2012) 315-319.

3. T.R.F. Njoku, and B.E.B. Nwoko, Prevalence of paramphistomiasis among sheep slaughtered in some selected abattoirs in Imo State, Nigeria, Science World J. 4 (2009) 12-15.

4. N. Ozdal, A. Gul, F. Ilhan, and S. Deger, Prevalence of paramphistomum infection in cattle and sheep in Van Province, Turkey, Helminthologia. 47 (2010) 20-24.

5. N.M. Armani, N.K.H. Saraswati, I.M.G. Sutawijaya, and Yunanto., Surveilans parasit gastrointestinal pada ternak sapi dan kerbau di Provinsi Bali, NTB dan NTT tahun 2016. Buletin Veteriner, Balai Besar Veteriner Denpasar. (2017) 48-66.

6. E. Murtiyeni, Juarini, dan J. Manurung. Penyakit parasit pada ternak ruminansia. Bogor: Balai Penelitian Veteriner, 2009.

7. M.R. Ilha, A.P. Loretti, and A.C. Reis, Wasting and mortality in beef cattle parasitized by Eurytrema coelamaticum in the state of Parana, Southern Brazil, Vet. Parasitol. 133 (2005) 49-60.

8. M.Q. Bilal, A. Hameed, and T. Ahmad, Prevalence of gastrointestinal parasites in buffalo and cow calves in rural areas of Toba Tek Singh, Pakistan, J. Anim. Plant Sci. 19 (2009) 67-70.

9. M.K. Khan, M.S. Sajid, M.N. Khan, Z. Iqbal, and M.U. Iqbal, Bovine fasciolosis: Prevalence, effects of treatment on productivity and cost benefit analysis in five districts of Punjab, Pakistan, Res. Vet. Sci. 87 (2009) 70-75.

10. J.U. Khan, T. Akhtar, A. Maqbool, and A. Anees, Epidemiology of paramphistomiasis in buffaloes under different managemental conditions at four districts of Punjab Province, Pakistan, Iran. J. Vet. Res. 7 (2006) 68-72.

11. V. Tandon, B. Roy, J.A. Shylla, and S. Ghatani. Amphistomes. In: Toledo, R., dan Fried, B. (Eds.). Digenetic trematodes. New York: Springer. 2014. 12. M.A. Taylor, R.L. Coop, and R.L. Wall. Veterinary parasitology. $4^{\text {th }} \mathrm{ed}$.
Oxford: Wiley Blackwell. 2016

13. T.W. Sardjono. Helmintologi kedokteran dan veteriner. Malang: Universitas Brawijaya Press. 2017.

14. F. Kristiyani, N. Aini, and Wijayanti A.D., Evaluasi pengobatan trematodiasis menggunakan albendazol pada sapi di Kecamatan Pakem, Sleman, Daerah Istimewa Yogyakarta, Jurnal Sain Veteriner. 37 (2019) 104-111.

15. M.H. Babu, J.K. Rao, and T.V.V.S.R Reddi. Ethnoveterinary medicine of Eastern Ghats Ajacent Deccan Region. In: Pullaiah, T., Krishnamurty, K.V., dan Bahadur, B. (Eds.). Ethnobotany of India Volume 1. Oakville: Apple Academic Press Inc. 2017.

16. Z. Iqbal, S.M Akhtar, Z. Sindhu, M.N. Khan, and A. Jabbar, Herbal deflukeers in livestock - a traditional therapy. Int. J. Agric. Biol. 5 (2003) $1-7$.

17. R. Kumarasingha, S. Preston, T-C Yeo, D.S.L. Lim, C-L. Tu, E.A. Palombo, J.M. Shaw, R.B. Gasser, and P.R. Boag, Anthelmintic activity of selected ethno-medicinal plant extracts on parasitic stages of Haemonchus contortus. Parasit. Vectors. 9 (2016) 199-206.

18. S.G. Wynn, and B.J. Fougere. Veterinary herbal medicine. St. Louis: Mosby. 2007.

19. J.M.Y. Cormanes, H.P. Portugaliza, and M.M. Quilicot, In vivo anthelmintic activity of pineapple (Ananas comosus Merr.) fruit peeling juice in semi-scavenging Philippine native chicken naturally co-infected with Ascaridia galli and Heterakis gallinarum. Livest. Res. Rural. Dev. 28 (2016) 1-12.

20. S.B. Widodo, Uji aktivitas jus limbah nanas (Ananas comosus (L) Merr) sebagai antelmintik cacing usus pada sapi. Thesis, Universitas Mataram, Mataram, 2019.

21. D. Lawal, Medicinal, pharmacological, and phytochemical potentials of Ananas comosus Linn. peel - a review. Bajopas. 6 (2013) 101-104.

22. M.F.A. Al-Amura, Z.A. Hassen, and B.H. Al-Mhanawi, Staining technique for helminth parasites by use red beet (Beta vulgaris L.) extract. Bas. J. Vet. Res. 11 (2012) 283-292.

23. Y. Watanabe, S. Nishida, K. Zenke, H.K. Hui, N. Itoh, and T. Yoshinaga, Development of the macronucleus of Cryptocaryon irritans, a parasitic ciliate of marine teleosts, and its ingestion and digestion of host cell. Fish Pathol. 52 (2016) 112-120.

24. H. Mehlhorn. Encyclopedia of parasitology. 3rd ed. New York: Springer. 2008

25. N. Lorsuwannarat, et al., 2014. The in vitro anthelmintic effects of plumbagin on newly excysted and 4-weeks-old juvenile parasites of Fasciola gigantica. Exp. Parasitol. 136 (2014) 5-13.

26. C.M. Hendrix and E. Robinson. Diagnostic parasitology for veterinary technicians.5th ed. New York: Elsevier. 2017.

27. K.M. Husson, N.A.M. Oliver, and M.W. Robinson, Paramphistomosis of ruminants: an emerging parasitic disease in Europe. Trends Parasitol. 33 (2017) 836-844

28. V. Choudhary, et al., Morphological and histological identification of Paramphistomum cervi (Trematoda: Paramphistoma) in the rumen of infected sheep. Vet. World. 8. (2015) 125-129.

29. D. Masih, N. Singh, and A. Singh, Red Beetroot: A source of natural colourant and antioxidants: A review. J. Pharmacogn. Phytochem. 8 (2019) 162-166

30. M.I. Udonkang, I.J. Inyang, A.N. Ukorebi, F. Effiong, U. Akpan, and I.E. Bassey, spectrophotometry, physiochemical properties, and histological staining potential of aqueous and ethanol extracts of beetroot on various tissues of an albino rat. Biomed. Hub. 3 (2018) 1-10.

31. J.P. Zryd and C. Laurent, Betalain. In: Davies K. (Eds). Plant pigments and their manipulation. Oxford: Annual Plant Review. 2004.

32. J.A. Rattenbury. Specific staining of nucleolar substance with acetocarmine. Stain Technol. 27 (1952) 113-120.

33. G.J.H. Grubben, and O.A. Denton. Plant resources of Tropical Africa 2. Wageningen: PROTA Foundation/Backhuys Publisher/CTA. 2004

34. V. Sivakumar, J.L. Anna, Vijayeeswarri, and G. Swaminathan, Ultrasound assisted enhancement in natural dye extraction from beetroot for industrial applications and natural dyeing of leather. Ultrason. Sonochem. 16 (2009) 782-789

35. M. Yeniocak, O. Goktas, M. Colak, E. Ozen, and M. Ugurle, Natural coloration of wood material by red beetroot (Beta vulgaris) and determination color stability under UV exposure. Technol. 17 (2015) 711722.

36. D. Plumb. Plumb's veterinary drug handbook. 7th ed. Stockholm: PharmaVet. Inc. 2011

37. S.T. Purnamasari, 2017. Uji aktivitas anthelmintik ekstrak etanol daun jarak pagar (Jatropha curcas Linn) terhadap cacing Paramphistomum sp. secara in vitro. Thesis, Universitas Hasanuddin, Makassar, 2017

38. E. Hossain, G. Chandra, A.P. Nandy, S.C. Mandal, and J.K. Gupta, Anthelmintic effect of a methanol extract of Bombax malabaricum leaves 
on Paramphistomum explanatum. Parasitol. Res. 110 (2012) 1097-1102.

39. N. Saowakon, N. Lorsuwannarat, N. Changklungmoa, C. Wanichanon, and P. Sobhon, Paramphistomum cervi: The in vitro effect of plumbagin on motility, survival and tegumentt structure. Exp. Parasitol. 133 (2013) 179-186.

40. J. Adli and S. Sundari, Daya antihelmintik nanas (Ananas comosus) terhadap Ascaris lumbricoides secara in vitro. Jurnal Mutiara Medika. 8 (2008) 107-112.

41. P. Anuracrpeeda, R. Chawengkirttikul, B. Panyarachun, P. Puttarak, P. Koedrith, and N. Intaratat, The In Vitro Anthelmintic activity of the ethanol leaf extracts of Terminalia catappa L. on Fasciola gigantica. Parasitol. p. 1-12. 2013.

42. D. Jacobs, F. Mark, G. Lynda, and H. Carlos, Principle of veterinary parasitology. Oxford: Wiley-Blackwell. 2015.

43. M. Kwolek-Mirek and R. Zadrag-Tecza, Comparison of methods used for assessing the viability and vitality of yeast cells. FEMS Yeast Res. 14 (2014) 1068-1079.

44. H.A. Shalaby, A.H. El Namaky, R.A. Kamel, and A.A Derbala, Tegumenttal surface changes in adult Paramphistomum microbothrium (Fischoeder 1901) following in vitro administration of artemether. J. Helminthol. 84 (2009) 115-122.

45. H. Hoste, F. Jackson, A. Spiridoula, S.M. Thamsborg, and S.O. Hoskin, The effects of tannin-rich plants on parasitic nematodes in ruminants.
Trends Parasitol. 22 (2006) 253-261

46. M.G.S. Septiadi, I.M. Dwinata, and I.B.M. Oka, Vermisidal dan ovisidal getah biduri (Calotropis spp.) terhadap Fasciola gigantica secara in vitro. Indonesia Medicus Veterinus. 5 (2016) 54-60.

47. H. Roy, Preliminary phytochemical investigation and anthelmintic activity of Acanthospermum hispidum DC. Journal of Pharmaceutical Science and Technology. 2 (2010) 217-221.

48. S. Poolperm and W. Jiraungskoorskul, An update review on the anthelmintic activity of bitter gourd, Momordica charantia. Pharmacogn. Rev. 11 (2017) 31-4.

49. Whiteland, H.L., et al., An abies procera-derived tetracyclic triterpene containing a steroid-like nucleus core and a lactone side chain attenuates in vitro survival of both Fasciola hepatica and Schistosoma mansoni. Int. J. Parasitol-Drug. 8 (2018) 465-474.

50. B.P.S. Capece, S. Calsamigliat, G. Castells, M. Arboix, and C. Cristofol, Effect of ruminal microflora on the biotransformation of netobimin, albendazole, albendazole sulfoxide, and albendazole sulfoxide enantiomers in an artificial rumen. J. Anim. Sci. 79 (2001) 1288-1294.

51. P. Frutos, G. Hervas, F.J. Giraldez, and A.R. Mantecon, Review tanin and ruminant nutrition. Span. J. Agric. Res. (2004) 191-202.

52. S.Y. Damiyati, I.S. Pratama, and G.Tresnani, Karakterisasi jus kulit nanas (Ananas comosus L. Merr). BioWallacea. 7 (2021) 84-90. 